\title{
An Experimental Study on Wear Performance of Electrolytic Multilayer Cu-Ni-Cr Coated ABS Under Different Test Forces
}

\author{
Sencer Süreyya KARABEYOĞLU ${ }^{1 a}$, Berkay ERGENE ${ }^{2 b^{*}}$, Çağın BOLAT ${ }^{3 c}$ \\ ${ }^{1}$ Kırklareli University, Faculty of Engineering, Department of Mechanical Engineering, Kırklareli, Turkey \\ ${ }^{2}$ Pamukkale University, Faculty of Technology, Department of Mechanical Engineering, Denizli, Turkey \\ ${ }^{3}$ Istanbul Technical University, Faculty of Mechanical Engineering, Istanbul, Turkey \\ bergene@pau.edu.tr
}

Received/Geliş: 17.01.2021

Accepted/Kabul: 29.03.2021

\begin{abstract}
Plastic materials are widely preferred in many applications due to being light and cheap in addition to being manufactured easily with various manufacturing methods like injection molding or additive manufacturing. One of the most used plastic material ABS (acrylonitrile butadiene styrene) is sometimes coated to increase its wear and corrosion resistance. In this study, investigating the effect of coating and test forces on wear behavior of injection-molded ABS specimens at room temperature were focused. For this purpose, ABS specimens were manufactured with injection molding technology and some samples were multilayer $\mathrm{Cu}-\mathrm{Ni}-\mathrm{Cr}$ coated step by step. Then, surface roughness values of prepared coated and uncoated specimens were measured by surface roughness profilometer. Subsequently, the micro view of the coated sample was obtained from an optical microscope after cutting the sample with the precision cutting machine. Lastly, the wear performance of coated and uncoated samples was tested under various loads such as $5 \mathrm{~N}, 7 \mathrm{~N}$, and $10 \mathrm{~N}$ by using pin-on-disc test equipment. In conclusion, surface roughness and wear level of samples were determined besides the average friction coefficient and friction forces. The results show that multilayer $\mathrm{Cu}-\mathrm{Ni}-\mathrm{Cr}$ coating affects the friction forces and average friction coefficient values significantly.
\end{abstract}

Keywords: Multilayer coating, Wear performance, ABS

\section{Elektrolitik Çok Katmanlı Cu-Ni-Cr Kaplı ABS'nin Farklı Test Kuvvetleri Altında Aşınma Performansı Üzerine Deneysel Bir Çalışma}

\begin{abstract}
Öz: Plastik malzemeler hafif ve ucuz olmalarının yanı sıra enjeksiyon kalıplama ve eklemeli imalat gibi çeşitli imalat yöntemleriyle kolayca üretilebildiği için birçok uygulamada yaygın olarak tercih edilmektedirler. En çok kullanılan plastik malzemelerden biri olan ABS zaman zaman aşınma ve korozyon direncinin artırılması amacıyla kaplanmaktadır. Bu çalışmada, enjeksiyon kalıplama ile üretilen ABS numunelerin aşınma davranışına kaplama ve test kuvvetlerinin etkisinin araştırılmasına odaklanılmıştır. Bu amaçla, ABS numuneler enjeksiyon kalıplama teknolojisiyle üretilmiş ve sonrasında bazı numuneler adım adım çok katmanlı $\mathrm{Cu}-\mathrm{Ni}-\mathrm{Cr}$ ile kaplanmıștır. Daha sonra, hazırlanan kaplamalı ve kaplamasız numunelerin yüzey pürüzlülük değerleri profilometre ile ölçülmüştür. Akabinde, kaplanan numune hassas kesme cihazı ile kesilerek, optik mikroskop ile mikro görüntüsü elde edilmiş̧ir. Son olarak, kaplamalı ve kaplamasız numunelerin aşınma performansı $5 \mathrm{~N}, 7 \mathrm{~N}$ ve $10 \mathrm{~N}$ gibi çeşitli yükler altında pin-on-disk aşınma cihazı ile test edilmiştir. Sonuç olarak, ortalama sürtünme katsayısı ve sürtünme kuvvetlerinin yanı sıra numunelerin yüzey pürüzlülüğü ve aşınma seviyesi belirlenmiştir. Sonuçlar, çok katmanlı $\mathrm{Cu}-\mathrm{Ni}$-Cr kaplamanın sürtünme kuvvetlerini ve ortalama sürtünme katsayısı değerlerini önemli ölçüde etkilediğini göstermektedir.
\end{abstract}

Anahtar Kelimeler: Çok katmanlı kaplama, Aşınma performansı, ABS 


\section{Introduction}

Acrylonitrile butadiene styrene (ABS) is a well-known thermoplastic polymer material created by a chemical reaction among the acrylonitrile, butadiene, and styrene [1]. As of few decades, ABS resin has been frequently utilized in various fields such as electronics, automobiles, building materials, and other industries owing to its versatile performance, comfortable processing, and molding [2]. ABS can also be named as a copolymer and meets design requirements at a low cost. This polymer is intense and rigid engineering material and can be used for performance and structural applications. Also, it has perfect chemical resistance and dimensionally stable [3]. On the other hand, ABS is notably suitable for additive manufacturing processes and this circumstance can be interpreted as a great advantage for its attractiveness in future real applications.

Recently, polymers are preferred in lots of industrial applications [4]. The replacement of metallic alloys with polymeric ones in new technological machines and systems has become pretty important and sliding, or in other words having high risks for wearing, parts of many design components are made of different kinds of plastics. Herein, ABS can also be counted good replacement for metallic parts. Up to now, especially for worn ABS components, many scientists have offered certain coating methods. In this context, Bazzaoui et al. [5] offered electro-nickel plating, and obtained coating layers without any pre-treatment. Sanchez-Valdes et al. [6] tried ultrasound irradiation techniques on ABS materials for effective coating. Mura et al. [4] used graphene as a solid lubricant on ABS samples and showed that graphene layers reduced friction coefficient values. Khan et al. [7] optimized the surface texture structure of nickel-coated layers of 3D printed ABS samples. Nigam et al. [8] applied copper plating to enhance tribological features and electrical conductivity of lightweight ABS and used the electric arc-spraying method. Shaikh et al. [9] studied electro-less nickel tungsten coating on 3D printed ABS substrates to improve wear and hardness properties. Kang et al. [10] reported that reflective and conductive silver films could be formed on ABS samples utilizing covalent grifting and solution spray. Diaz et al. [11] pointed out that the application of flame sprayed $\mathrm{Zn}$-Al coatings on ABS was possible without any chemical surface pre-treatment. Yang et al. [12] focused on hydrophobic surfaces on ABS surfaces and attained them via fused deposition modeling. Mayandi et al. [13] investigated friction and wear properties of polytetrafluoroethylene (PTFE) added ABS composites and indicated that increasing volume fraction of PTFE affected positively self-lubrication ability. Sukwisute et al. [14] coated ABS samples with a hard $\mathrm{CrN}$ layer to improve wear response and the research team claimed that the highest hardness levels were observed on $\mathrm{CrN}$ coated samples. Mohamed et al. [15] worked on the effects of additive manufacturing parameters on the wear properties of ABS and reported that the wear rate decreased with diminishing layer thickness but with rising in the air gap and raster angle. Nigam et al. [16] probed the sliding wear behavior of electric arc sprayed copper-coated ABS substrates. The same research group also simulated the wear mechanism to figure out the probable influences of copper coating layers [17]. Sudin et al. [18] compared the wear performance of ABS and ABS composites and found out that carbon fiber reinforced ABS showed less wear rate because of the high load-bearing capacity of carbon fibers. Matseevich et al. [19] recommended a blend of ABS and polyvinyl chloride (PVC) for applications of floor coverings as a result of their wear analyses. In another effort, Abdellah et al. [20] analyzed the mechanical wear behavior of short basalt fiber reinforced ABS and asserted that increasing the content of short basalt fibers caused better wear strength. Besides polymeric materials, some studies about other engineering materials are still examined [21-23].

In this experimental work, to comprehend detailed wear features of $\mathrm{ABS}$, electro $\mathrm{Cu}-\mathrm{Ni}-\mathrm{Cr}$ deposition technique was used and the results were compared with uncoated ABS samples. This method is not expensive and sophisticated in comparison with other high-cost laboratory-scale alternatives. Contrary to technical literature, all wear tests were conducted under different loading 
forces in unlubricated conditions, so probable effects of changing forces on weight loss, friction force, average friction coefficient value were detected.

\section{Material and Method}

Initially, all injection molded parts were manufactured by using LGmp220 ABS material. Then, half of them were coated to determine the effect of coating on wear performance of ABS parts at room temperature under various loads $(5 \mathrm{~N}, 7 \mathrm{~N}$, and $10 \mathrm{~N})$. Following this procedure, the ABS sample was cut by a precision cutting machine (ATM GMBH Brillant220) and the micro view from this sample was obtained with the help of an optical microscope (Olympus BX51TRF-6).

Since plastics do not have electrical conductivity like metals, they are first made conductive to coat them. In this context, firstly, a pre-abrasion was applied to the surfaces of the samples. Typically, the pre-abrasion bath is used to break the butadiene bonds within the ABS. It contains chromic acid and sulfuric acid as content. It was operated between $62-68{ }^{\circ} \mathrm{C}$. Then the activation solution was prepared. This solution is used to place $\mathrm{Sn}^{+2}$ and $\mathrm{Pd}^{+2}$ ions in butadiene bonds broken by abrasion. The room temperature was sufficient for the copper layer. The solution contained copper-sulfate $\left(\mathrm{CuSO}_{4} .5 \mathrm{H}_{2} \mathrm{O}\right)$ and sulfuric acid $\left(\mathrm{H}_{2} \mathrm{SO}_{4}\right)$. Besides, a brightener was added for a glossy coating. In electrolytic multilayer coating processes, the intermediate nickel layer is the thickest layer that enters between the upper chrome and the lower copper. Nickel plating bath was prepared from a mixture of nickel chloride $\left(\mathrm{NiCl}_{2}\right)$, nickel sulfate $\left(\mathrm{NiSO}_{4}\right)$, and boric acid $\left(\mathrm{H}_{3} \mathrm{BO}_{3}\right)$. The operating temperature was around $55{ }^{\circ} \mathrm{C}$. The solution $\mathrm{pH}$ was adjusted between 3.8 and 4.2. Finally, the chrome layer was coated. The bath content was made up of chromic acid $\left(\mathrm{CrO}_{3}\right)$ and sulfuric acid $\left(\mathrm{H}_{2} \mathrm{SO}_{4}\right)$ as much as $1 \%$ of chromic acid.

In Figure 1a, the coating layers sequence was demonstrated as an image obtained from an optic microscope (Olympus BX51TRF-6) and Figure 1b shows the macro scale images of worn uncoated and coated ABS parts under various test forces.

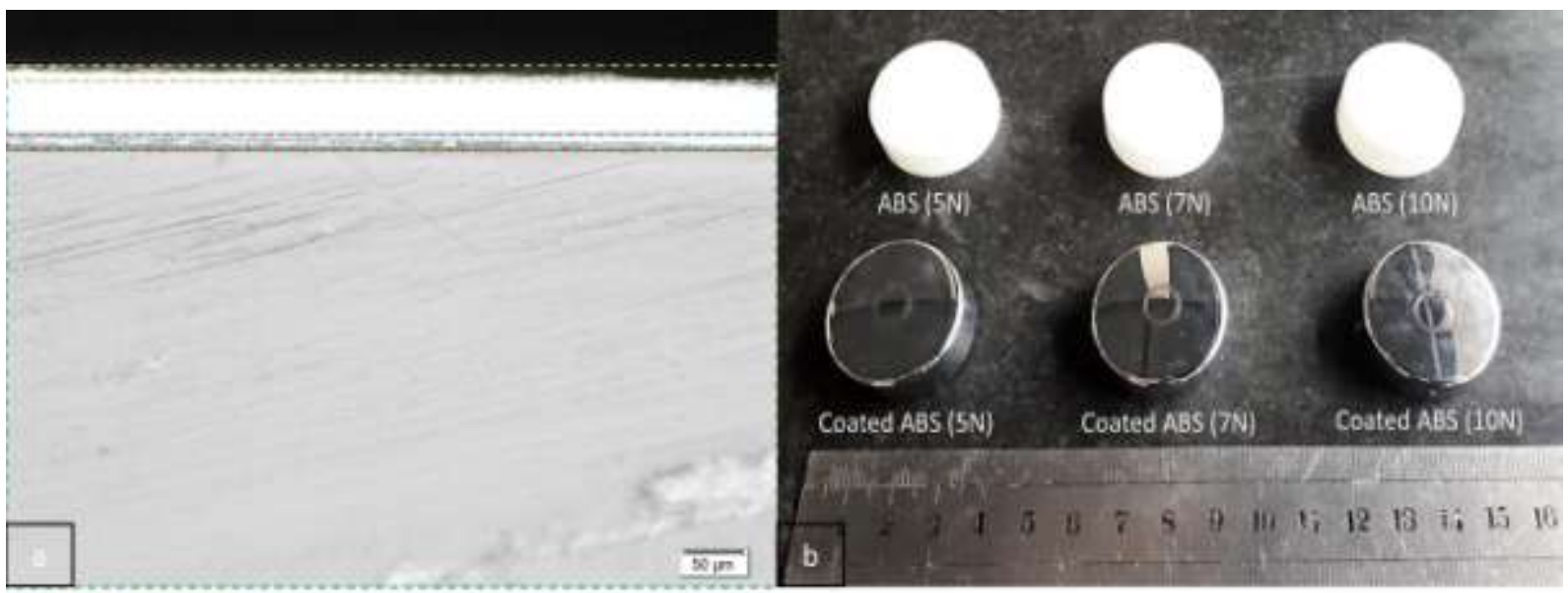

ABS $\mathrm{Cu} \quad \mathrm{Ni}$ i $\mathrm{Or} \rightarrow$ Demonatration of tren sequenc

Figure 1. Micro and macro views; a) demonstration of coating layers sequence, b) view of worn uncoated and worn coated ABS parts

Wear properties of all samples were determined using specially designed pin-on-disc test equipment (Turkyus Pod Ht\&Wt, Turkey). During wear tests, an alumina pin was used and its speed was assigned as $100 \mathrm{~mm} / \mathrm{s}$. Moreover, each wear test lasted at the end of 1500 second under three different test forces of $5 \mathrm{~N}, 7 \mathrm{~N}$, and $10 \mathrm{~N}$ at room temperature. 


\section{Results}

\subsection{Friction Forces}

Figure $2 \mathrm{a}$ and Figure $2 \mathrm{~b}$ display the change of friction forces during test under $5 \mathrm{~N}, 7 \mathrm{~N}$ and $10 \mathrm{~N}$ test forces for $\mathrm{ABS}$ and $\mathrm{Cu}-\mathrm{Ni}-\mathrm{Cr}$ coated ABS samples. According to Figure 2a, friction force values depend on the applied force during the experiment, and higher applied load results in higher friction force. In Figure $2 b$, friction forces that occurred during the experiment of ABS samples with coating were exhibited. If both Figure $2 a$ and Figure $2 b$ are compared, the effect of coating on friction forces can be realized clearly. Hence, friction forces rise with the presence of coating and the minimum friction force values at coated ABS samples are almost at the same level with maximum friction forces observed for uncoated ABS samples.
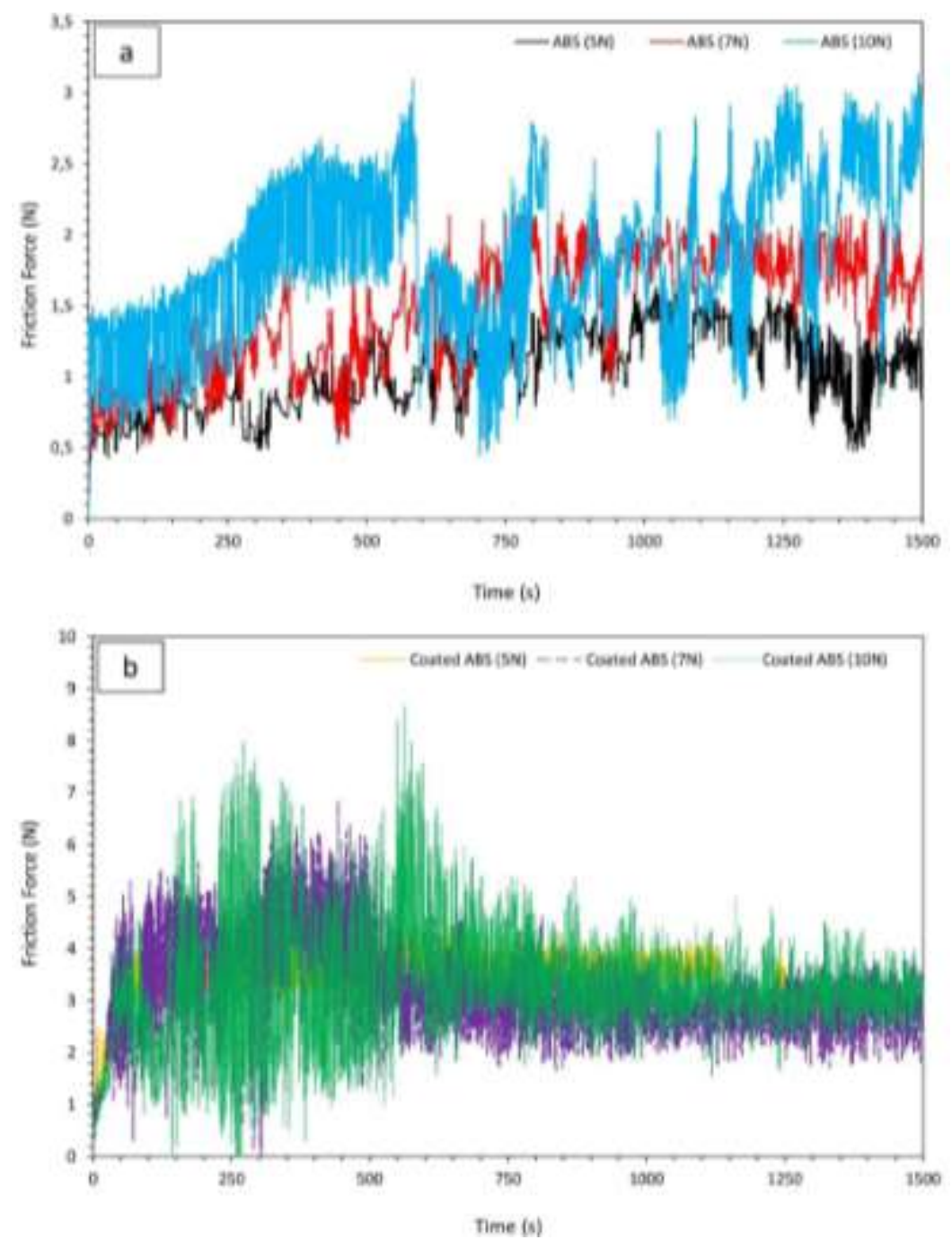

Figure 2. Friction force vs time graphs for ABS samples under different test forces, a) uncoated samples, b) coated samples

\subsection{Average Friction Coefficient and Surface Roughness}

It's known that investigating the effect of coating on materials is requisite to improve the wear performances of products that are subjected to abrasion. To observe the wear performances of Average friction coefficient/time graphs were given in Figure 3a and Figure 3b respectively for $\mathrm{ABS}$ and $\mathrm{Cu}-\mathrm{Ni}-\mathrm{Cr}$ coated ABS specimens. Firstly, it's clear that the average friction coefficient of ABS samples fluctuates during test duration and low-test forces lead to a higher average friction 
coefficient value. These obtained test results are compatible with the study conducted in the literature [18]. Moreover, average friction coefficient values of ABS samples change approximately between 0.10 and 0.33 while these values are much higher for coated ABS samples such as range between 0.10 and 0.80. Likewise, Gargh and Singh [24] examined a study on wear behavior of ABS and Nylon 6-Fe powder composite parts and they reported that when the level of the applied load has increased from $5 \mathrm{~N}$ to $20 \mathrm{~N}$ while the testing speed is constant $(200 \mathrm{r} / \mathrm{min})$, average friction coefficient decreased from 0,3 to 0,22 .
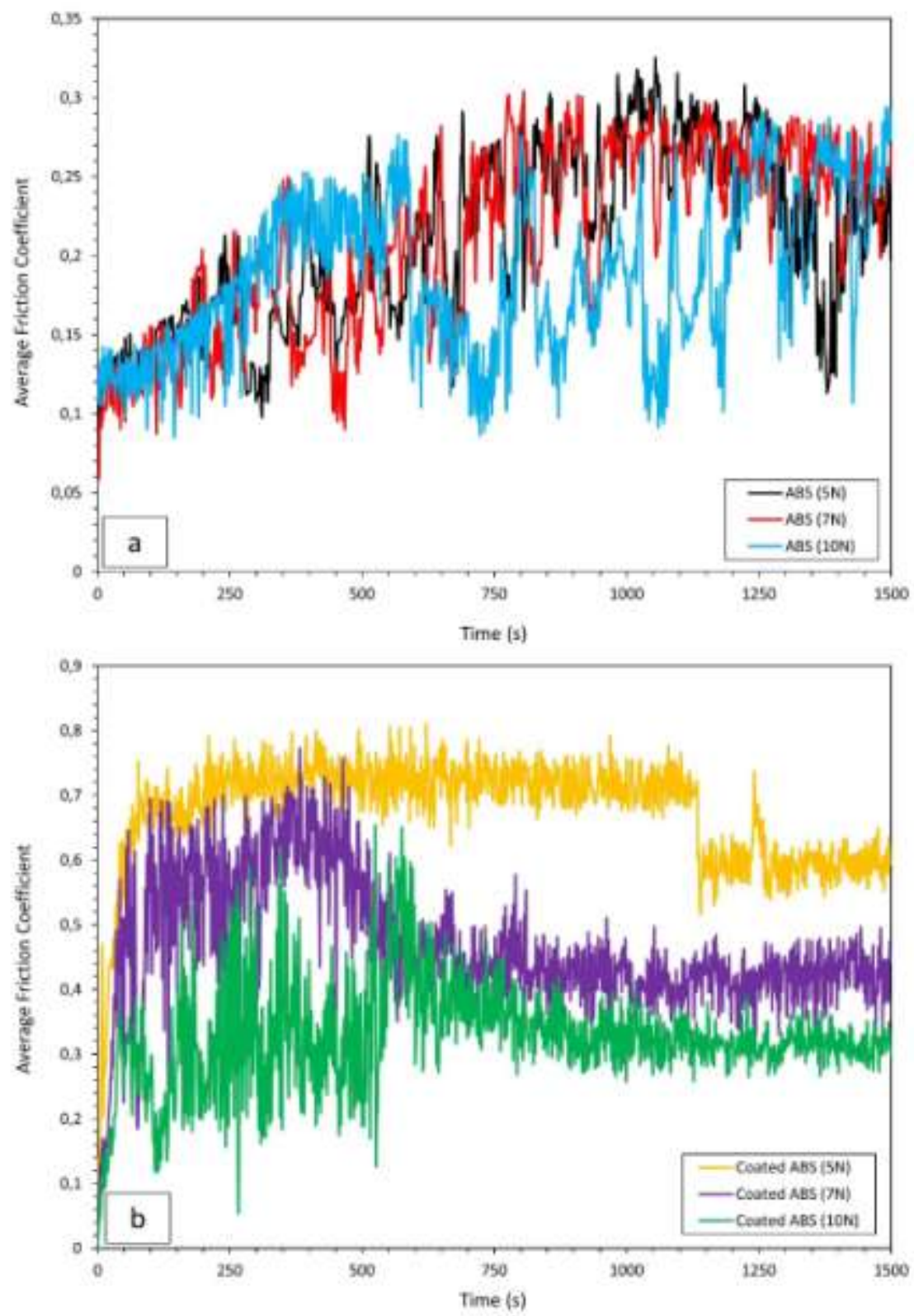

Figure 3. Average friction coefficient vs time graphs for different forces a) for ABS specimens, b) for coated ABS specimens

The surface roughness of industrial products is often undesirable, and various methods are tried in the studies conducted in the literature to minimize it. Besides, before obtaining friction forces and average friction coefficient values, the surface roughness of the ABS and coated ABS parts were also measured three times with the Hommel Tester T 500 surface roughness profilometer, and the average of these three measurements was determined as the surface roughness of the measured part. 
As can be seen from Figure 4, surface roughness values of ABS and coated ABS are pretty close to each other and $0,14 \mu \mathrm{m}$ and $0,15 \mu \mathrm{m}$ respectively. Also, the surface roughness value of the ABS sample is compatible with the measurements done in the researches in literature [25]. This result emphasizes that the applied coating does not significantly affect the surface roughness of ABS in this research though it can be a great potential to minimize the high surface roughness of additively manufactured ABS parts [26].

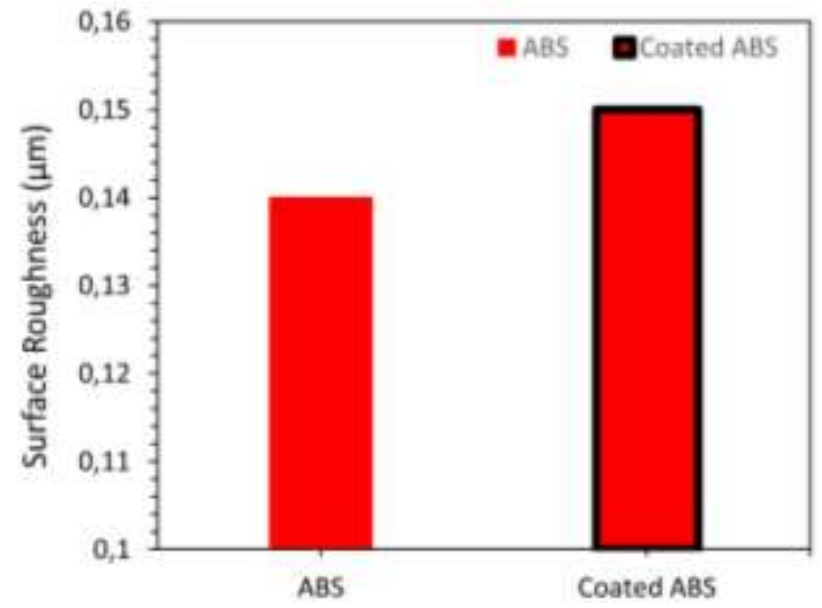

Figure 4. Surface roughness of ABS and coated ABS specimens

\subsection{Wear Amount}

The graphic regarding the effect of the coating on the wear amounts under different forces in ABS samples is given in Figure 5. From Figure 5, it is obvious that the effect of coating on ABS samples is visible for all test forces from $5 \mathrm{~N}$ to $10 \mathrm{~N}$. On the other hand, the wear amount difference between coated and uncoated ABS samples decreases when the applied force increases. Additionally, it can be pointed out that the presence of coating provides a better protective property against wear mechanism for lower test forces like $5 \mathrm{~N}$. Besides, these findings are in line with studies in the literature investigating the amount of wear of coated and uncoated samples $[4,14]$

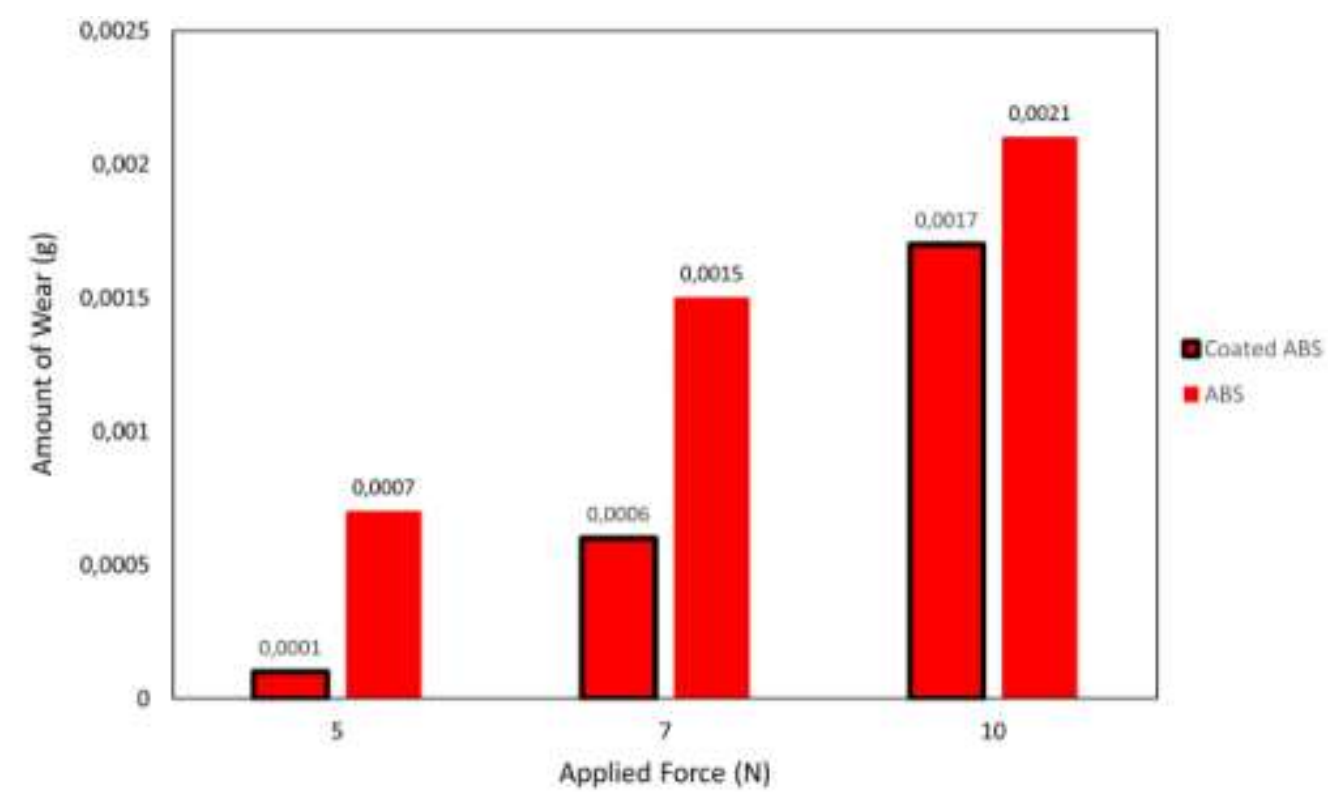

Figure 5. Applied force vs amount of wear graph for coated and uncoated ABS samples under different loads 
Lastly, the examination of the mechanical performance of coated ABS specimens as well as the wear behavior is among the current topics. At this point, additively manufacturability of ABS samples with desired computer-aided design by using FDM, PolyJet, selective laser sintering, and laminated object manufacturing methods provide significant convenience to the researcher and developers [27].

\section{Conclusions}

In this study, coated and uncoated ABS samples were compared to see the effect of the coating under various test forces, and the major following outcomes can be listed as;

- Electrolytic multilayer $\mathrm{Cu}-\mathrm{Ni}-\mathrm{Cr}$ coating process is an effective way to enhance wear performance of ABS polymers and can be counted as a promising alternative for expensive methods.

- Coated ABS samples effectuate higher friction forces and average friction coefficient values when compared with uncoated ABS samples.

- Similarly, to the tendency of frictional forces, coated ABS samples display higher average friction coefficient values than uncoated samples.

- The amount of wear rises with the increase of test force and coating has a significant effect to reduce the amount of wear.

- The surface roughness values of ABS and coated ABS are quite similar to each other and measured as $0,14 \mu \mathrm{m}$ and $0,15 \mu \mathrm{m}$.

\section{Acknowledgment}

The author would like to thank PGS Plastics Wood Metal Coating Industry and Trade Ltd. Co. firm for their assistance in coating process. In addition, Application and Research Center of Innovative Technologies in Süleyman Demirel University is gratefully acknowledged for the technical support.

\section{Authors' contributions}

SSK, BE and ÇB carried out the works, analyzes and wrote up the article. The authors read and approved the final manuscript.

\section{Competing interests}

The authors declare that they have no competing interests.

\section{References}

[1]. Han, Y., Lach, R., Grellmann, W, Effects of rubber content and temperature on unstable fracture behavior in ABS materials with different particle sizes, J. Appl. Polym. Sci., 2001, 79: 9-20.

[2]. Li, Y., Wu, X., Song, J., Li, J., Shao, Q., Cao, N., Lu, N., Guo, Z., Reparation of recycled acrylonitrile- butadiene-styrene by pyromellitic dianhydride: Reparation performance evaluation and property analysis, Polymer, 2017, 124: 41-47.

[3]. Singh, N., Singh, R., Reference Module in Materials Science and Materials Engineering, 2017. 
[4]. Mura, A., Adamo, F., Wang, H., Leong, W.S., Ji, X., Kong, J., Investigation about tribological behavior of $\mathrm{ABS}$ and $\mathrm{PC}-\mathrm{ABS}$ polymers coated with graphene, Tribology International, 2019, 134: 335-340.

[5]. Bazzaoui, M., Martins, J.I., Bazzaoui, E.A., Albourine, A., Environmentally friendly process for nickel electroplating of ABS, Applied Surface Science, 2012, 258: 7968-7975.

[6]. Avila-Alfaro, J.A., Sánchez-Valdes, S., Ramos-deValle, L.F. et al. Ultrasound Irradiation Coating of Silver Nanoparticle on ABS Sheet Surface. J Inorg Organomet Polym, 2013, 23: 673-683.

[7]. Khan, M.S., Mishra, S.B., Kumar, M.A., Banerjee, D., Optimizing Surface Texture and Coating Thickness of Nickel Coated ABS-3D Parts, Materials Today, 2018, 5: 19011-19018.

[8]. Nigam, S., Mahapatra, S.S., Patel, S.K., Study of various aspects of copper coating on ABS plastic by electric arc spraying, Materials Today: Proceedings, 2018, 5: 8446-8453.

[9]. Shaikh, M.S.N.M., Ahuja, B.B., Optimization of electroless nickel tungsten composite coating on 3d-printed ABS substrate for maximum tungsten content. J. Inst. Eng. India Ser. C, 2020, . https://doi.org/10.1007/s40032-020-00630-2.

[10]. Kang, Z., Chen, D., Zhang, Y., Bessho, T., Kudo, T., Sang, J., Hirahara, H., Mori, K., Formation of reflective and conductive silver film on ABS surface via covalent grafting and solution spray, Applied Surface Science, 2015, 349: 503-509.

[11]. Diaz, D.G.A., Navarro, R.G.V., Godoy, N.O., Pingarrón, A.B., Parra, J.R.G., Florez, J.J.O., Barragán, M.T., Moncaleano, I.A., Otalora, C.A.O., Flame-sprayed Zn-Al coatings on ABS without chemical surface preparation, Materials Letters, 2020, 280: 128574.

[12]. Yang, H., Ji, F., Li, Z., Tao, S., Preparation of hydrophobic surface on PLA and ABS by fused deposition modeling, Polymers, 2020, 12: 1-14.

[13]. Mayandi, K., Kumar, R.M., Rajini, N., Ayrilmis, N., Friction and wear properties of PTFE blended ABS polymer composite, AIP Conference Proceedings, 2019, 2057: 020046, https://doi.org/10.1063/1.5085617.

[14]. Sukwisute, P., Sakdanuphab, R., Sakulkalavek, A., Hardness and wear resistance improvement of ABS surface by $\mathrm{CrN}$ thin film, Materials Today: Proceedings, 2017, 4: 65536561.

[15]. Mohamed, O.A., Masood, S.H., Bhowmik, J.L., Analysis of wear behavior of additively manufactured PC-ABS parts, Materials Letters, 2018, 230: 261-265.

[16]. Nigam, S., Patel, S. K., Mahapatra, S. S., Sliding wear analysis of a metallic coating on ABS plastic substrate. Applied Mechanics and Materials, 2016, 852: 381-387

[17]. Nigam, S., Mahapatra, S.S., Patel, S.K., Numerical modelling of sliding wear caused by pinon-disk method over copper coated ABS plastic substrate, IOP Conf. Ser.: Mater. Sci. Eng., 2016, 149: 1-7.

[18]. Sudin, M.N., Ramli, F.R., Alkahari, M.R., Abdullah, M.A., Comparison of wear behavior of $\mathrm{ABS}$ and $\mathrm{ABS}$ composite parts fabricated via fused deposition modelling, International Journal of Advanced and Applied Sciences, 2018, 5: 164-169.

[19]. Matseevich, A., Matseevich, T., Askadskii, A., Study of the abrasion resistance of woodpolymer composites and mixtures of ABS-plastic with polyvinyl chloride, MATEC Web of Conferences, 2018, 196, 04069.

[20]. Abdellah, M.Y., Fathi, H.I., Abdelhaleem, A.M.M., Dewidar, M., Mechanical properties and wear behavior of a novel composite of acrylonitrile-butadiene-styrene strengthened by short basalt fiber. J. Compos. Sci., 2018, 2: 1-12.

[21]. Döleker, K.M., ZrO2-5\%CaO termal bariyer kaplama (TBC) sisteminin sıcak korozyon direnci, El-Cezeri Journal of Science and Engineering, 2020, 7: 628-638.

[22]. Uçar, K., Şen, U., Friction and wear properties of T6 treatment and as-plated duplex NiP/NiB coatings on Az91d magnesium alloy. El-Cezeri Journal of Science and Engineering, 2019, 6: $31-42$. 
[23]. Ergene, B., Bolat, Ç. Determination of thermal stress and elongation on different ceramic coated Ti-6Al-4V alloy at elevated temperatures by finite element method. Sigma Journal of Engineering \& Natural Sciences, 2020, 38: 2013-2026.

[24]. Garg, H.K., Singh, R., Comparison of wear behavior of ABS and Nylon6-Fe powder composite parts prepared with fused deposition modelling. J. Cent. South Univ., 2015, 22: 3705-3711.

[25]. Monterde, J.G., Soto, M.G., Maspoch, M.L., Influence of injection molding parameters on the morphology mechanical and surface properties of ABS foams. Advanced Polymer Technology, 2018, 37: 2707-2720.

[26]. Yalçın, B., Ergene, B., Endüstride yeni eğilim olan 3-B eklemeli imalat yöntemi ve metalurjisi. SDU International Journal of Technological Science, 2017, 9: 65-88.

[27]. Olivera, S., Muralidhara, H.B., Venkatesh, K., Gopalakrishna, K., Vivek, C.S., Plating on acrylonitrile-butadiene-styrene (ABS) plastic: A review. J. Mater. Sci., 2016, 51: 3657-3674. 